\title{
Operation and monitoring guidelines and the development of a screening tool for irrigating with coal mine water in Mpumalanga Province, South Africa
}

\author{
Danie Vermeulen ${ }^{1 *}$ and Brent Usher ${ }^{1}$ \\ ${ }^{1}$ Institute for Groundwater Studies, University of the Free State, PO Box 339, Bloemfontein 9300, South Africa
}

\begin{abstract}
It is predicted that vast volumes of impacted mine water will be produced by mining activities in the Mpumalanga coalfields of South Africa. Irrigation provides for a novel approach to the utilisation and disposal of mine water, under the correct conditions. The significance of these findings lies in the versatility of this irrigation. Communities which often have very few other resources can utilise mine water to generate livelihoods. Research over a period of more than 10 years has shown that this water can be used successfully for the irrigation of a range of crops. The potential environmental impact of this excess water is of great concern in a water-scarce country like South Africa. There is, however, continuing concern from the local regulators regarding the long-term impact that large-scale mine-water irrigation may have on groundwater quality and quantity. Detailed research has been undertaken over the past number of years on both undisturbed soils and in coal-mining spoils. These sites range from sandy soils to very clayey soils. The results indicate that many of the soils have considerable attenuation capacities and that over the period of irrigation, a large proportion of the salts are contained in the upper portions of the unsaturated zones below each irrigation pivot. The volumes and quality of water leaching through to the aquifers have been quantified at each site. From these data mixing ratios were calculated in order to determine the effect of the irrigation water on the underlying aquifers.

One of the outcomes from this study was to define the conditions under which mine-water irrigation can be implemented and the associated operational and monitoring guidelines that should be followed. These have been based on the findings from this study, the fundamental considerations of mine-water irrigation, the regulatory environment and, as far as possible, the practical implementation of mine-water irrigation as part of optimal mine-water management. In an attempt to standardise decision-making regarding mine-water irrigation, the criteria, data, rules and fundamentals discussed have been combined in a user-friendly tool, called GIMI (Groundwater Impacts from Minewater Irrigation). This tool should assist in the practical implementation of mine-water irrigation as part of optimal mine-water management.
\end{abstract}

Keywords: irrigation, coal mine water, monitoring guidelines

\section{Introduction}

South Africa is a water-poor country. With increased industrialisation and population growth, the demands on this resource are increasing. South Africa is the fourth largest producer of coal in the world, and the $224 \times 10^{6} \mathrm{t}$ of coal produced per year directly supports employment for approximately 50000 employees. Unfortunately, several waterrelated problems, largely associated with water quality deterioration due to pyrite oxidation, occur, as a result of mining.

Huge volumes of mine water, impacted on by the phenomenon of acid mine drainage, are presently being produced as a result of mining activities in the Mpumalanga coalfields (Fig. 1). When released into water environments, the high salinities of this water are responsible for unacceptable water quality degradation.

Coal extraction has been ongoing at the Mpumalanga Coalfields for more than 100 years. Coal is

\footnotetext{
* To whom all correspondence should be addressed. 푱 +2751 4012482; fax: +27514446538 or 0866531049 e-mail: VermeulenD.SCI@ufs.ac.za Received 12 November 2008; accepted in revised form 31 March 2009.
}

generally mined by opencast- or underground methods in South Africa. Underground mining comprises in excess of 100000 ha, while opencast mining is expected to eventually exceed 40000 ha (Grobbelaar et al., 2002). In opencast areas, much of the groundwater influx is dependent on the state of post-mining rehabilitation, while in underground mining, factors such as

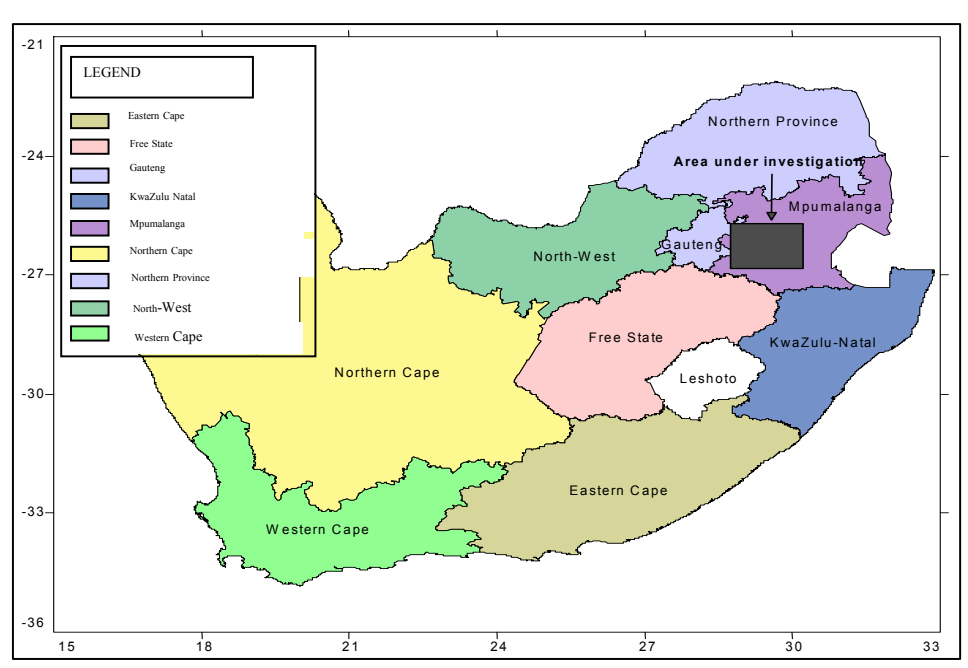

Figure1

Map of South Africa, indicating the area under investigation 


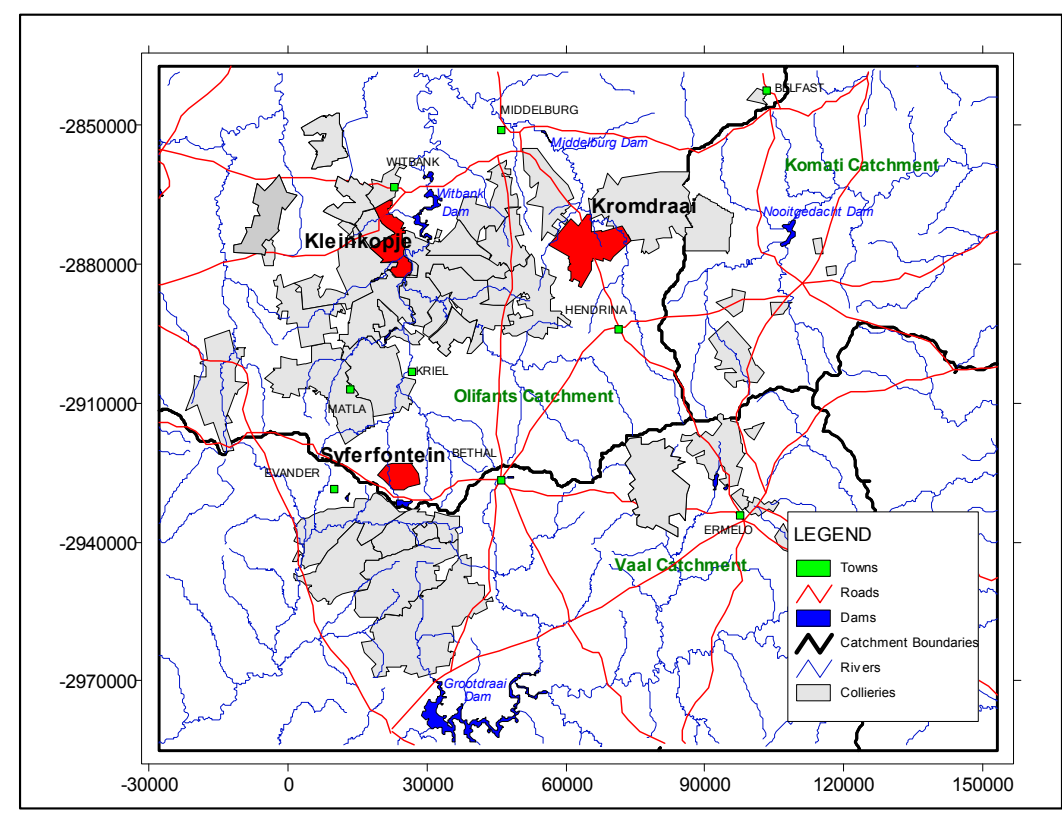

Figure 2

Position of the collieries of Mpumalanga where most of the research has been done

the mining type, depth and degree of collapse and interconnectivity is important.

After the closure of mines, water in the mined-out areas will flow along the coal seam floor and accumulate in the lower-lying areas. These voids will fill up with water, and hydraulic gradients will be exerted onto peripheral areas (barriers) or compartments within mines. This results in water flow between mines, or onto the surface eventually. This flow is referred to as inter-mine flow (Grobbelaar, 2001). Projections for future volumes of water to decant from the mines have been made by Grobbelaar et al. (2000). In total, about $360 \mathrm{Ml} / \mathrm{d}$ will decant from all the mines in combination. In a water-stressed country like South Africa, all water must be regarded as a potential resource, and there is potentially a tremendous resource that can be utilised by activities such as irrigation, provided the environmental impact is not excessive. This water can be utilised by previously disadvantaged communities for job creation and for their economic benefit. Irrigation provides for a novel approach to the utilisation and disposal of mine water, under the correct conditions.

This research investigated the impact of these activities on groundwater resources at irrigation pivots at collieries across the coalfields of South Africa (Fig. 2), where mine-water irrigation has been done for periods ranging from a few years to more than seven years.

\section{Water quality impacts}

Associated with coal mining in South Africa, the phenomenon of acid mine drainage (AMD) occurs. Acid mine drainage occurs when sulphide minerals in rock are oxidised, usually as a result of exposure to moisture and oxygen. This results in the generation of sulphates, metals and acidity. Pyrite $\left(\mathrm{FeS}_{2}\right)$ is the most important sulphide found in South African coalmines. When exposed to water and oxygen, it can react to form sulphuric acid $\left(\mathrm{H}_{2} \mathrm{SO}_{4}\right)$. The following oxidation and reduction reactions give the pyrite oxidation that leads to acid mine drainage.

(1) $\mathrm{FeS}_{2}+7 / 2 \mathrm{O}_{2}+\mathrm{H}_{2} \mathrm{O}=>\mathrm{Fe}^{2+}+2 \mathrm{SO}_{4}^{2-}+2 \mathrm{H}^{+}$

(2) $\mathrm{Fe}^{2+}+1 / 4 \mathrm{O}_{2}+\mathrm{H}+=>\mathrm{Fe}^{3+}+1 / 2 \mathrm{H}_{2} \mathrm{O}$
(3) $\mathrm{Fe}^{3+}+3 \mathrm{H}_{2} \mathrm{O}=>\mathrm{Fe}(\mathrm{OH})_{3}+3 \mathrm{H}^{+}$

(4) $\mathrm{FeS}_{2}+14 \mathrm{Fe}^{3+}+8 \mathrm{H}_{2} \mathrm{O}=>15 \mathrm{Fe}^{2+}+2 \mathrm{SO}_{4}^{2-}+16 \mathrm{H}^{+}$

(Stumm and Morgan, 1996).

In the South African coalfields there are co-existing carbonates such as calcite and dolomite, which can neutralise the acidity generated (Usher, 2003) Alternatively the acidity can be neutralised by lime addition, as is done with acidic water pumped from the Kleinkopje Colliery workings in Emalahleni.

From the overall reaction of calcite as buffering mineral, it is evident that calcium and sulphate will increase in concentration:

(5) $\mathrm{FeS}_{2}+2 \mathrm{CaCO}_{3}+3,75 \mathrm{O}_{2}+1,5 \mathrm{H}_{2} \mathrm{O} \Leftrightarrow \mathrm{Fe}(\mathrm{OH})_{3}+2 \mathrm{SO}_{4}^{2}$ $+2 \mathrm{Ca}^{2+}+2 \mathrm{CO}$

This increase in $\mathrm{Ca}^{2+}$ and $\mathrm{SO}_{4}^{2-}$ can only occur up to a point, where the aqueous solubility of these ions becomes limited by the solubility of gypsum $\left(\mathrm{CaSO}_{4} \cdot 2 \mathrm{H}_{2} \mathrm{O}\right)$. Using the PHREEQC geochemical model (Parkhurst and Appello, 1999), the saturation state of the neutralised mine water used to irrigate was determined (Fig. 3). The results show that the gypsum approached saturation $(\mathrm{SI}=0)$ for most of the values. The implication of this is that when irrigation takes place, some evaporation, together with the selective uptake of essential nutrients, will result in gypsum precipitation.

Gypsum is a partially soluble salt. Concentrating the gypsiferous soil solution through crop evapotranspiration precipitates gypsum in the soil profile and therefore removes it from the water system (see Table 1 for irrigation water quality), reducing potential pollution (Annandale et al., 2002).

\section{Sustainability of irrigation with gypsiferous mine water}

Annandale et al. (2002) did the initial work regarding irrigation with gypsiferous water in South Africa. The commercial production of several crops irrigated with gypsiferous mine water was tested in a field trials since 1997. From these trials, it was observed that no foliar injury was observed due to sprinkle irrigation with gypsiferous mine water, and that 


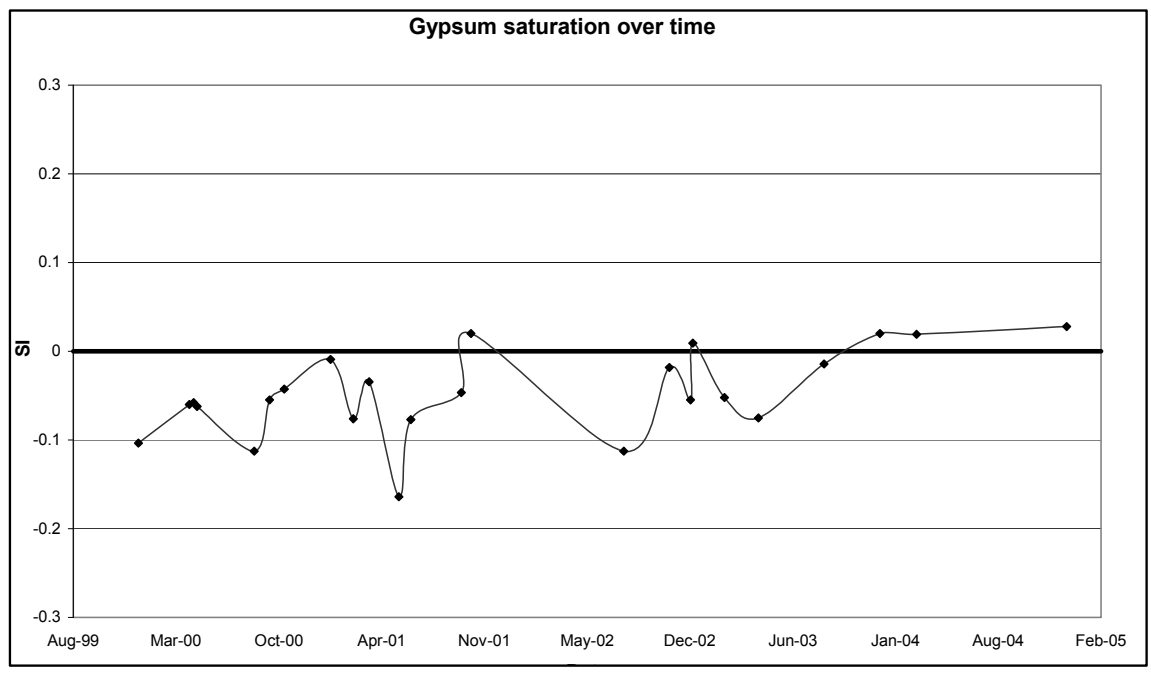

Figure 3

Gypsum saturation

(SI) in neutralised

mine water used

to irrigate at

Kleinkopje Pivot 1

\begin{tabular}{|c|c|c|c|c|c|c|c|c|c|c|c|}
\hline \multicolumn{12}{|c|}{$\begin{array}{l}\text { TABLE } 1 \\
\text { Average water quality of the irrigation water at one of the sites }\end{array}$} \\
\hline $\mathrm{pH}$ & $\begin{array}{c}\mathrm{EC} \\
\mathrm{mS} / \mathrm{m}\end{array}$ & $\begin{array}{c}\mathrm{Ca} \\
\mathrm{mg} / \mathrm{l}\end{array}$ & $\begin{array}{c}\mathrm{Mg} \\
\mathrm{mg} / \ell\end{array}$ & $\begin{array}{c}\mathrm{Na} \\
\mathrm{mg} / \mathrm{l}\end{array}$ & $\begin{array}{c}\mathrm{K} \\
\mathrm{mg} / \mathrm{l}\end{array}$ & $\begin{array}{c}\text { Alkalinity } \\
\text { as } \mathrm{mg} / \ell \mathrm{CaCO}_{3}\end{array}$ & $\begin{array}{c}\mathrm{Cl} \\
\mathrm{mg} / \ell\end{array}$ & $\begin{array}{c}\mathrm{SO}_{4} \\
\mathrm{mg} / \mathrm{l}\end{array}$ & $\begin{array}{c}\mathrm{Fe} \\
\mathrm{mg} / \ell\end{array}$ & $\begin{array}{c}\mathrm{Mn} \\
\mathrm{mg} / \mathrm{l}\end{array}$ & $\begin{array}{c}\mathrm{Al} \\
\mathrm{mg} / \ell\end{array}$ \\
\hline 6.21 & 344 & 578 & 242 & 52 & 12.9 & 34 & 12 & 2550 & 3.1 & 10.3 & 0.01 \\
\hline
\end{tabular}

possible nutritional problems, such as deficiencies in $\mathrm{K}, \mathrm{Mg}$ and $\mathrm{NO}_{3}$, occurring due to $\mathrm{Ca}$ and $\mathrm{SO}_{4}$ dominating the system, can be solved through fertilisation. Crops like sugar-beans, wheat and maize were found to be commercially viable. The finding from the research was that gypsiferous mine water for irrigation is sustainable for crop production in the short term (3 years) with negligible impact on the soil salinity.

Groundwater monitoring has been undertaken at these sites by Grobbelaar and Hodgson (1997 to 2001) and by Usher et al. (2001 to 2006). Observation of limited water quality impacts in the groundwater over time has prompted the research in the vadose zone below the root zone of each irrigated area.

In order to determine the hydraulic behaviour, salt balances and attenuation, and the movement of the salts at the various irrigation sites, tensiometer experiments have been performed on site. Moisture potentials were calculated from the tensiometer data (data from Kleinkopje Pivot 1 is used for illustration of the results).

Analysis of the tensiometer data over time, continued groundwater and soil-water monitoring and detailed analysis of the soil characteristics as far as hydraulic and mass transport properties at each site, allowed the development of accurate conceptual models of the interaction between irrigation and the underlying soils and aquifers. The results pointed to several potentially significant findings for the wider application of mine water irrigation. A general model for irrigation sites indicates the following:

The clay-rich layers (Table 2) play an important role in the migration, with a build-up of salts above these layers (Fig. 4). The clay is important in limiting the vertical flux. Data from soil analysis with depth through the profile indicates that most of the salt is contained in the top $2 \mathrm{~m}$ of the profile.

Tensiometer data indicate that the soil throughout the profile is high in moisture content, with the exception of the top 0.5 to $1 \mathrm{~m}$. On average the moisture content is above $30 \%$ (Table 3), as calculated from Hutson (1983) and Hensley (2006). Porous cup data indicate that most of the salts in the soil water

\begin{tabular}{|l|c|c|c|c|c|}
\hline \multicolumn{7}{|c|}{ TABLE 2 } \\
\hline $\begin{array}{l}\text { Sivot } \\
\text { Name }\end{array}$ & $\begin{array}{c}\text { Depth } \\
\text { (m) }\end{array}$ & Sand & $\begin{array}{c}\text { Coarse } \\
\text { silt }\end{array}$ & Fine silt & Clay \\
\hline KK1 & $0-0.4$ & 79.19 & 5.18 & 9.34 & 4.67 \\
\hline KK1 & $0.4-0.8$ & 78.39 & 9.74 & 4.62 & 4.62 \\
\hline KK1 & $0.8-1.0$ & 73.74 & 10.30 & 13.93 & 0.00 \\
\hline KK1 & $1.0-2.5$ & 61.11 & 16.46 & 9.29 & 18.58 \\
\hline KK1 & $2.5-2.8$ & 66.33 & 15.37 & 9.24 & 9.24 \\
\hline
\end{tabular}

are retained in the upper $2 \mathrm{~m}$ of the soil profile, as illustrated by the sulphate concentrations in Fig. 5. Chemical modelling of the soil water indicates saturation of the water with respect to gypsum above $1 \mathrm{~m}$, implicating gypsum precipitation (Fig. 3). Deeper down the soil water is unsaturated with regard to gypsum. Approximately $80 \%$ of the salts applied over the years of irrigation are retained. Data from soil-water analysis obtained of the porous cup sampling indicate that a lot of these salts occur in the soil water (about 30 to $0 \%$ of the total salts applied), and that the balance precipitates in the upper $2 \mathrm{~m}$ of soil or becomes adsorbed.

While the attenuation capacity of clays is a well-established concept, the long-term viability of irrigating with water influenced by coal mining is not widely accepted by regulators in South Africa. The groundwater monitoring results indicate that this attenuation makes mine-water irrigation a viable option in the short to medium term where gypsum-saturated waters are used, as analysis of the water in the aquifers below show limited increase in degradation in quality, except in sandy soils.

\section{Identifying water and land suitable for irrigation}

One of the outcomes of this study was to define the conditions under which mine-water irrigation can be implemented and the 


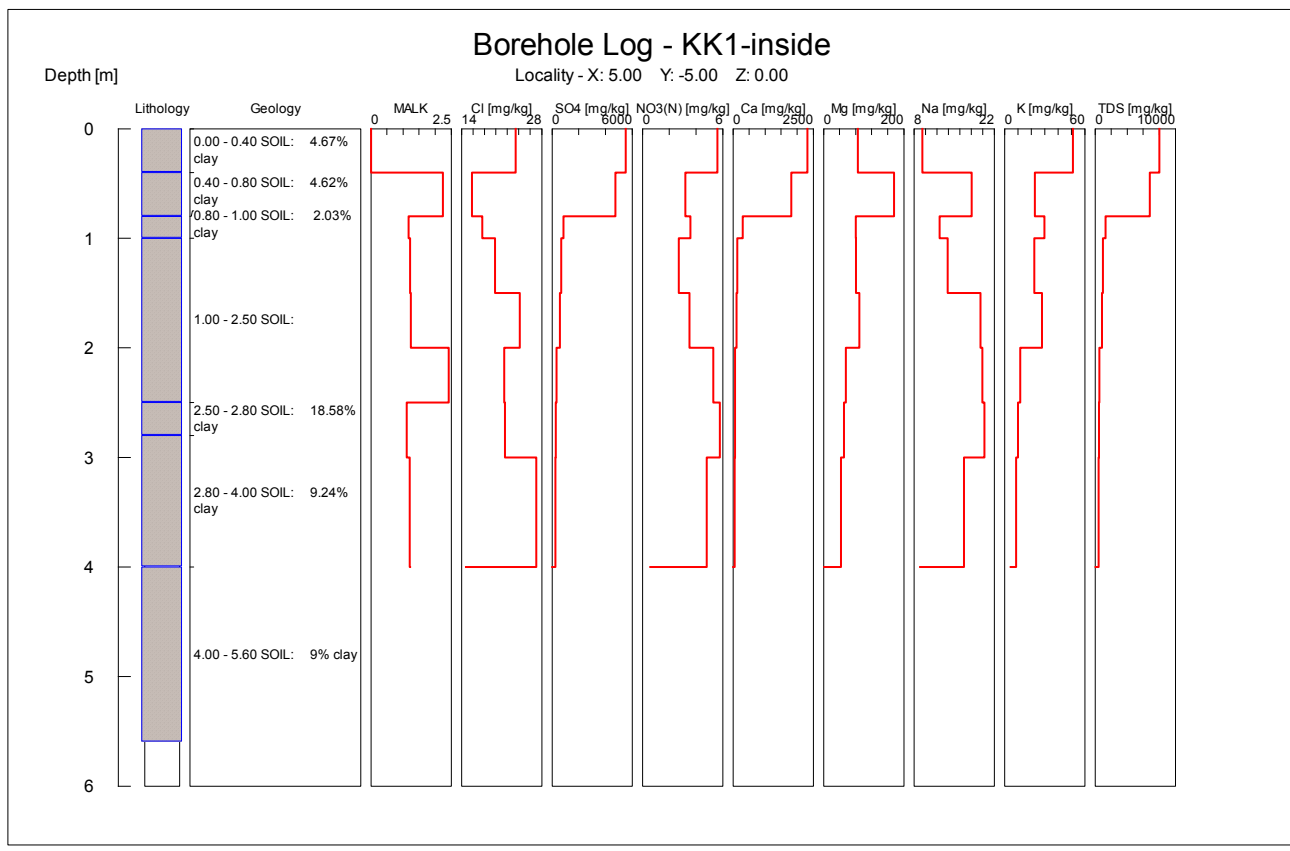

Figure 4

Soil leaching analyses with depth within Kleinkopje

Pivot 1

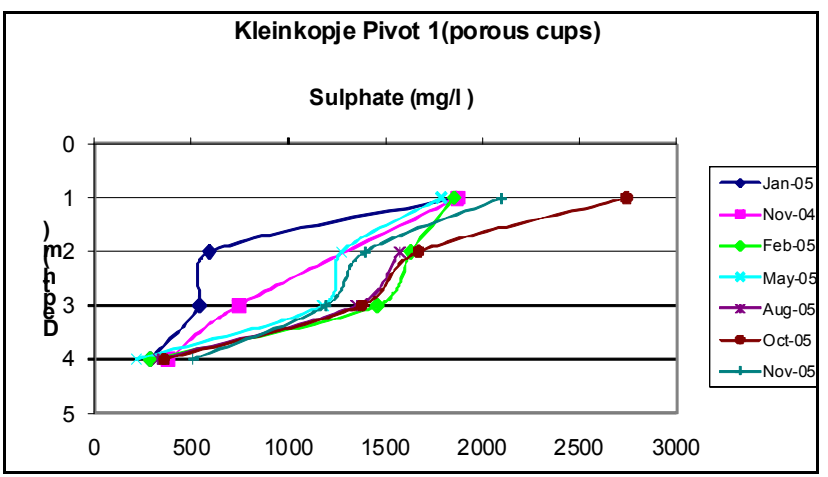

Figure 5

Sulphate concentrations with depth in the soil water at Kleinkopje Pivot 1

associated operational and monitoring guidelines that should be followed. Rules have been established for mine-water irrigation based on the findings of this study, the fundamental considerations of mine-water irrigation, the regulatory environment and, as far as possible, the practical implementation of mine-water irrigation as part of optimal mine-water management.

The rationale used to provide guidance on site selection, monitoring and operations is summarised by:

Figure 6 indicates that there are basic data that need to be provided before any kind of decision on the sustainability of mine-water irrigation can be made. Several so-called critical flaws have also been identified by this research. The presence of these flaws will lead to an immediate recommendation that

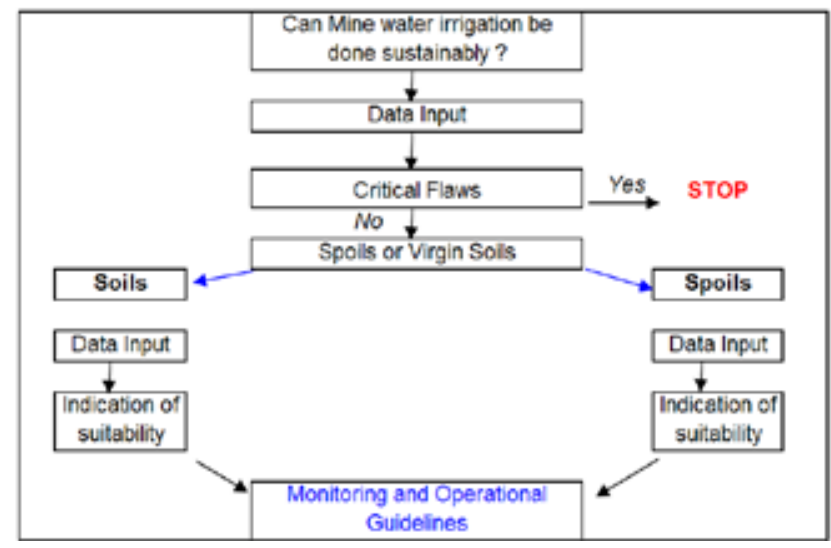

Figure 6

Rationale for defining site-specific criteria

irrigation with mine water should not occur. If none of these flaws is present, the decision can be made as to whether minewater irrigation is to be done on undisturbed soils (green fields) or on rehabilitated mine spoils (brown fields). Criteria for each type of irrigation have been identified and included in this decision-making process.

Figure 7 shows the type of information considered when defining the suitability of a particular site and the type of irrigation planned (duration, water quality, crop, etc.).

To facilitate consistent application of the findings and principles established in this research, it was decided to follow an approach according to which information of different types is considered and from this provide a screening tool for site

\begin{tabular}{|l|c|c|c|c|c|c|c|}
\hline \multicolumn{7}{|c|}{ TABLE 3 } \\
\multicolumn{7}{|c|}{ Moisture values at Kleinkopje Pivot $\mathbf{1}$ (Hutton soil) } \\
\hline $\begin{array}{l}\text { Depth } \\
\text { (mm) }\end{array}$ & \multicolumn{7}{c|}{ Estimated $\theta \mathbf{v}$ at different $\psi$ salues (mm water) } \\
\cline { 2 - 9 } & Saturation & $\mathbf{5 0 0}$ & $\mathbf{1 0 0 0}$ & $\mathbf{1 5 0 0}$ & $\mathbf{2 0 0 0}$ & $\mathbf{2 5 0 0}$ & $\mathbf{3 0 0 0}$ \\
\hline 1000 & 37.7 & 34.7 & 31.7 & & & & \\
\hline 2000 & 35.8 & 33.8 & 31.8 & 31 & 30.2 & 29.4 & 28.6 \\
\hline 3000 & 34 & 30.9 & 27.8 & & & & \\
\hline
\end{tabular}




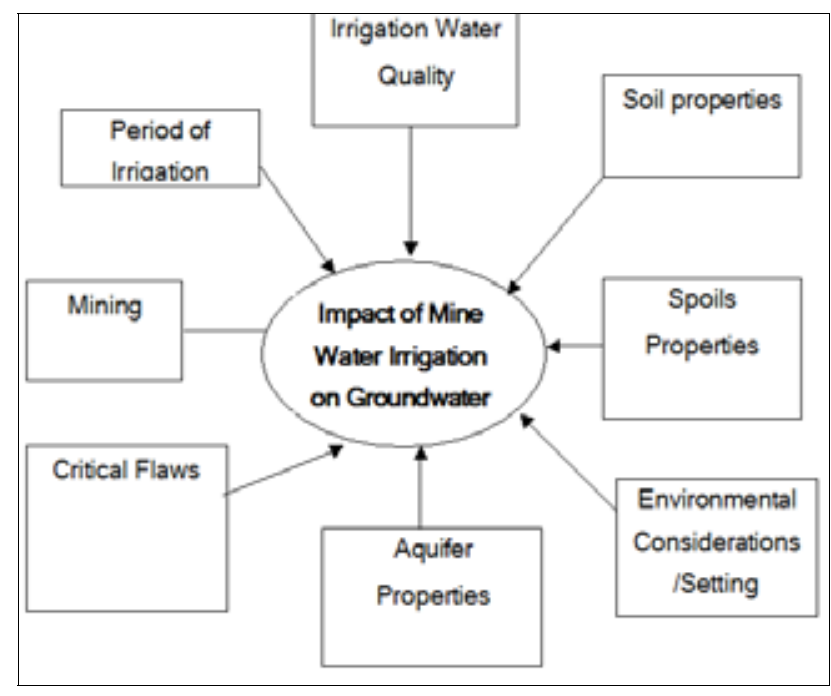

Figure 7

Data input required to determine impact and define criteria

selection, operation and management. As such, this screening tool provides guidance on these aspects and considers a wide variety of information. The intention of this tool is not to give accurate information on irrigation scheduling and crop selection, but rather to use environmental data and simplifying assumptions to provide a screening mechanism for decision making.

A set of critical flaws for mine-water irrigation has been identified. These flaws are situation-related to the location, water quality and receiving environment. If any of these criteria occur on site, mine-water irrigation should be carefully reconsidered as an appropriate water use or mine-water management option.

The critical flaws have been defined as follows:

- No irrigation is allowed with potable water (defined as TDS $<900 \mathrm{mg} / \ell$ or EC $<150 \mathrm{mS} / \mathrm{m}$ ) for basic human needs (BHN)

- Aquifer classification: If the irrigation is planned on a shallow sole source aquifer, it is a critical flaw

- Area of irrigation: If the area is greater than 150 ha, the criteria used in this document may not be appropriate for decision-making since no current research has been done on such a scale. The success of current irrigation is also due to the relatively small scale of application.

- Water quality: The irrigation water must be suitable for crop production. If the irrigation water $\mathrm{pH}<5$, or if $\left(\mathrm{Ca}+\mathrm{SO}_{4}+\mathrm{HCO}_{3}\right)$ in meq is $<60 \%$ of the total ionic composition (unless $\mathrm{EC}<200 \mathrm{mS} / \mathrm{m}$ ), or if the irrigated water is less than one and a half times that of the background EC, then irrigation cannot be allowed. Also if the SAR $>15$, then this is a critical flaw and irrigation should not be allowed.

- Land type: If the assessment for soil suitability is $\mathrm{N}$, this is considered to be a critical flaw. If there is a clay layer with a clay $\%$ more than $10 \%$ greater than the average for that soil type and this occurs less than $1 \mathrm{~m}$ below the root zone, this is a critical flaw.

- Water level: Groundwater level $<1.5 \mathrm{~m}$

- Depth of soil: Less than $0.5 \mathrm{~m}$ soils

- Community dependence on groundwater: If community dependence on groundwater $>80 \%$, it is a critical flaw unless the community is $>2 \mathrm{~km}$ away or up-gradient of the proposed irrigation or irrigation is planned for a very short period of time.

- Land stability: If pivot site is in an area of land instability, if there are sinkholes or if there is an underlying dolomitic aquifer, this would constitute a critical flaw.

- Environmental: If there is a wetland, nature reserve, Ramsar site or a site similar down-gradient within $2 \mathrm{~km}$, this is critical flaw.

Critical flaws should highlight potential situations where minewater irrigation is likely to cause long-term problems. However, with detailed determination of the on-site conditions, and potential monitoring and mitigation, irrigation in such areas may still be possible. The most important question then before irrigation can be introduced is to establish whether or not the land is suitable for irrigation.

Soil is often the only medium for dumping saline water. Using wastewater for crop production under irrigation seems like a perfect solution as it can be financially beneficial as well. However, the soil is not always the perfect sink and the environment must be protected. Protection of the environment is often seen as a good reason to pollute the soil with degraded water, assuming that the soil is a perfect sink and/or the soil is not part of the environment. The extent to which the soil serves as a good sink varies. Soil can effectively remove environmental hazards without it or the surrounding environment becoming polluted, but usually either the soil or the groundwater is polluted. Irrigation of soil with gypsum-rich water is an example of where the soil may serve this goal well. If the composition of the irrigation water is favourable for precipitation of gypsum in the soil, the gypsum may be removed from the water effectively. After precipitation the impact of the salt on crops is drastically reduced. In the dissolved condition the severity of divalent salinity is very low compared to sodium chloride solutions.

Procedures for selecting land for irrigation would include site properties including land suitability for irrigation:

- Soil types (well drained, moderately drained and poorly drained)

- Terrain morphological unit in the landscape containing the highest percentage of land suitable for irrigation

- Take slope into account. Different irrigation methods accommodate slope differently. Select crops resistant to salinisation.

- Irrigation area size (ha)

- Irrigation water quality

- Aquifer classification

- Geology and geological structures including karst and instability

- Volume-related aspects (water level, rainfall, irrigation volumes)

The suitability of soils for irrigation primarily depends on 4 factors.

Firstly the final infiltration rate of the soil must be high enough to prevent run off. The final infiltration rate is mainly determined by the soil texture, soil surface structure and slope.

Secondly, irrigation soil must have good internal drainage. The water must move through the root zone freely to avoid water logging. The factors controlling internal drainage are complicated but fortunately the soil morphology, as accommodated in the South African soil classification system, is a good indicator of internal drainage.

Thirdly, irrigation soil must have good external drainage 
as excess water, needed for leaching, must be able to move out of the system and join either the groundwater or surface water in rivers and wetlands. The factors controlling the external drainage are even more complicated than those controlling internal drainage. Soil morphology, specific redox morphology, also serves as a good indicator of external drainage and therefore the soil types of the South African soil classification system are classified according to the degree of drainage. Limited drainage is aggravated by the position in the landscape or terrain morphological unit (TMU).

Fourthly, the water-holding capacity (WHC) of a soil must be great enough to hold water for one irrigation cycle, usually one week. This limitation can be reduced by systems that can irrigate more often. Mechanical irrigation like dripand micro- irrigation must be avoided as they are probably unsuitable for use with saline water as the leaching factor cannot be upheld with them.

The principles applied in developing these soil suitability ratings were modified to fit the requirements of the area and quality of the irrigation water. Several factors contribute to the decision to make the drainage requirements stricter. The rainfall of the area is high, increasing the risk of water-logging. The criteria for soil depth are therefore more strict than usual. Saline water combined with water-logging increases the risk of salinisation and puts more emphasis on soil depth.

Additional factors are:

- Closest community (upgradient/downgradient, dependence on groundwater)

- Monitoring system (number of boreholes, distance of these boreholes from the site, monitoring frequency, and current groundwater quality)

At opencast sites, there are 2 main issues to consider. One important factor is the rehabilitated soils on top, and the other the spoils underneath.

\section{Rehabilitated soils}

- Depth of soil (value in mm)

- Type of soil: The same criteria as for undisturbed soil in an area are used (this can be carried over from undisturbed soil input), or site-specific soil properties (\% clay, loam and sand) must be considered

\section{Spoils}

- Is it free draining?

- Potential for acidity (assume that it is potentially acidgenerating (PAG) unless other data exist). Based on available data, either potentially acid-generating, non-acidgenerating or uncertain spoils will be used. Site-specific ABA data can be included.

- The proportion of spoils unit to be irrigated (either percentage, or enter total spoils area draining to decant point and area of mine-water irrigation)?

- Water use (will decant water be reused for irrigation)?

- Is any decant released to the environment, currently or in the future?

- What $\%$ of spoils is flooded at the decant elevation (\% value)?

- To what degree can gases enter the spoils?

\section{Monitoring guidelines}

If the potential site fulfils all the criteria set out in the previous section, appropriate monitoring must be put in place. Since the suggested monitoring must meet DWAF requirements, the most appropriate manner in which to deal with such irrigation is to apply the DWAF Minimum Requirements for Monitoring at Waste Disposal Facilities. DWAF (2005) states that monitoring networks at waste management facilities must allow monitoring of the system on a representative basis, and that the key to successful monitoring is the linking of point information into larger systems, referred to as monitoring networks. As such it is recommended that these DWAF guidance documents should provide the minimum monitoring requirements at mine-water irrigation sites and that the monitoring 'should extend beyond pollution plumes to allow for the delineation of plumes and investigations into the pollution migration rate.'

Based on the observations from the research and DWAF (Department of Water Affairs and Forestry, now Department of Water and Environment Affairs) Minimum Monitoring Requirements, it is suggested that for each pivot where minewater irrigation is undertaken, the following groundwater monitoring is recommended:

- Prior to installation, a detailed conceptual model of the site geohydrology should be constructed so that appropriate monitoring is put in place

- As the system is installed, detailed measurements and observations of the geology and aquifer characteristics should be done (using techniques such as slug or pump testing, etc.), and the conceptual model verified. These data will also allow a more accurate determination of the expected impact of the irrigation activities.

- At each pivot site at least one up-gradient and 2 downgradient boreholes should be installed, with a borehole pair near the centre of the pivot itself

- The boreholes on the outside of the irrigation must be constructed in a manner which is consistent with DWAF's Minimum Monitoring Requirements document

- The borehole pair within the pivot should be installed as follows:

- One shallow borehole that is drilled down to the top of the hard rock underlying the irrigation area, to below the weathered zone. This borehole should have a very short length of solid casing followed by slotted casing or a borehole screen to the bottom of the borehole. If the material is not competent, it is recommended that a slotted piezometer be installed with a gravel pack to ensure that the shallow groundwater can be accurately characterised.

- In close proximity, a deeper borehole should be drilled into the Karoo formation. This borehole must be isolated from the weathered zone.

- Proper sanitary seals and/or other preventative measures should be put in place to prevent the irrigation water from flowing directly into the boreholes

- Water levels should be measured in each borehole on a monthly basis. Groundwater sampling for the macroconstituents should be done at least 6 monthly, and before and after each crop is planted and harvested.

- Data should be compiled into a database and handled as prescribed in DWAF's Minimum Requirements (2005).

\section{GIMI - A user-friendly decision support application for mine water irrigation}

In an attempt to standardise decision-making regarding minewater irrigation, the criteria, data, rules and fundamentals discussed in the preceding sections have been combined in a 


\section{Groundwater Impact from Minewater Irrigation}

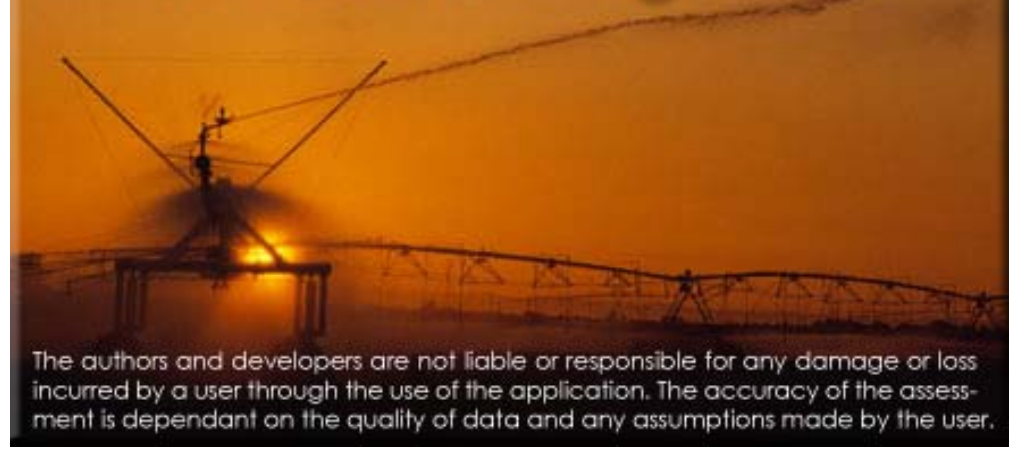

Figure 8

Groundwater Impacts from Mine Water Irrigation assessment tool

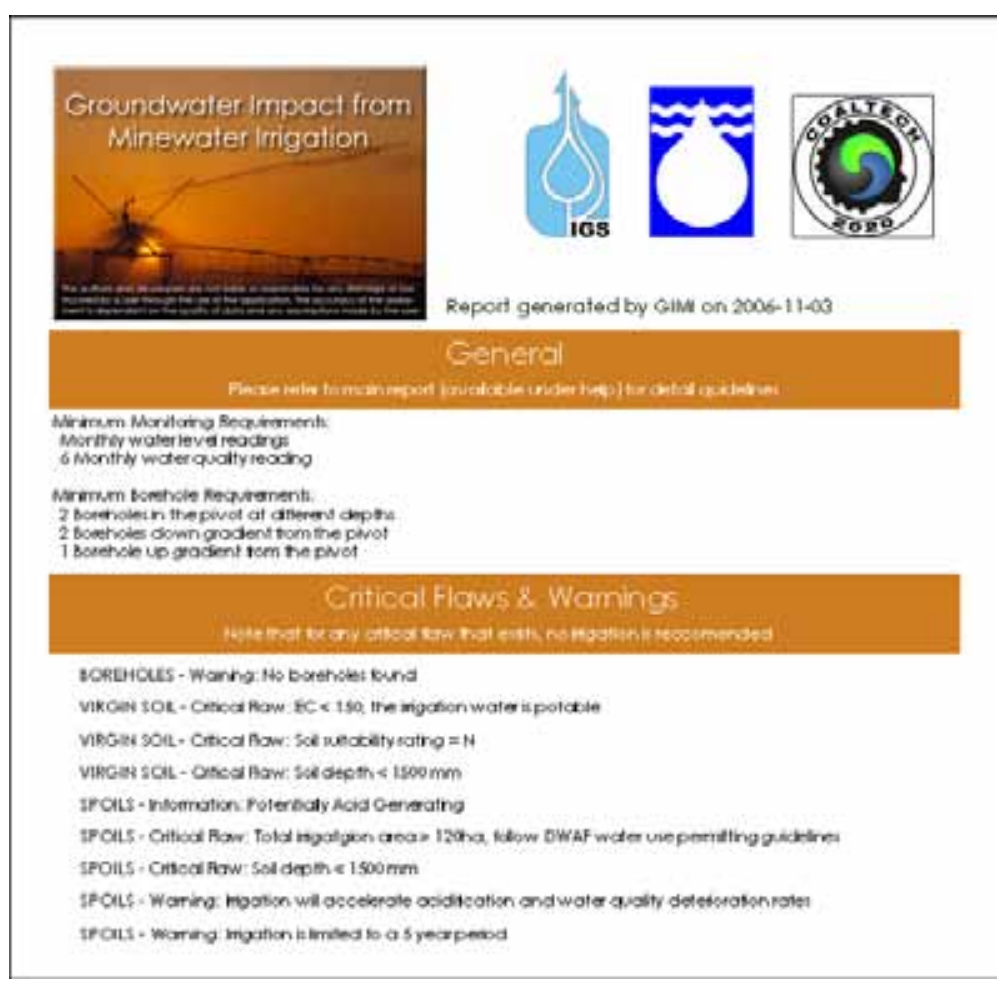

Figure 9

Groundwater impact report

user-friendly tool, called GIMI (Groundwater Impacts from Mine-water Irrigation). This tool is available from the Water Research Commission.

GIMI is a screening tool to help users make informed decisions about mine-water irrigation (Fig. 8). GIMI consist of a GIS system which contains all the base maps as shape files and an assessment interface where scenarios are built using a CAD interface. A soil map links the detailed soil information directly to the area of irrigation.

In terms of irrigation water quality, GIMI has a few features which will greatly assist users in determining the eventual impacts. The water quality input can either be done manually or can be linked to a WISH database or Excel sheet. This water quality can be scrutinised for relative ionic contribution (see 'critical flaws'), SAR indices and EC/TDS ratios for comparison to aquifer water. Additionally a link has been built to the PHREEQC geochemical model. This will enable correct determination of the concentration and equilibration of the water as volumes are reduced. This ensures that waters remain in ionic balance, and equilibrium with gypsum, calcite and dolomite. The mass of precipitated minerals can also be determined in this manner. The impact on receptors can be determined by using the concentration and load as determined by the PHREEQC and the water balance equations, and the Domenico (1987) approach (based on the advection-dispersion partial-differential equation for organic contaminant transport processes in groundwater). The time span of irrigation, the distance to the receptor and the water quality objective (where none is present, the SA drinking water standards for EC/TDS are used as default) at this receptor can be used to assess applicability.

A summary of all assessment object types are:

- Mine or area object which from the parent of all objects in the object tree

- Model object that represents the transport model

- Contour map object (topography, water levels and concentration)

- Quality object representing the mine-water quality

- Virgin soils

- Spoils object

- Pivot object, which is placed on the virgin soils or spoils

- Crop object, which is connected to pivot objects

- Acid based accounting object connected to the spoils

- Borehole object, which is placed on the area (mine) and acts as a receptor

- Population object, which is placed on the area (mine) and acts as a receptor

- Receptor object, which is placed on the area (mine)

Each object consists of properties. Some properties are user supplied and some are calculated from the system.

Once the assessment has been built through the available objects and the user is confident that all data requirements have been addressed the assessment can be run. An assessment, highlighting critical flaws and warnings, is generated in a report, as illustrated in Fig. 9. From this the suitability of the land and water for irrigation can be determined.

\section{Recommendations}

Irrigation with mine water must be implemented such that the environmental impacts are minimised. Based on the slow 
expected salinity build-up observed at the different sites, it is recommended that irrigation be done on an alternating basis (i.e. alternating between 2 pivots over time), if site criteria selection has been adhered too, and that mine-water irrigation should not be done for periods exceeding 10 years in any particular area. A non-negotiable prerequisite is that appropriate monitoring must be put in place at such a site. These boreholes must be constructed in such a way that they monitor all the different flow zones and aquifers at these sites.

To standardise decision-making regarding mine-water irrigation, the Groundwater Impacts from Mine Water Irrigation Tool (GIMI) is recommended (Vermeulen et al., 2008).

\section{Acknowledgements}

Funding from Water Research Commission and Coaltech 2020.

\section{References}

ANNANDALE JG, JOVANOVIC NZ, CLAASSENS AS, BENADE N, LORENTZ SA, TANNER PD, AKEN ME and HODGSON FDI (2002) The Influence Of Irrigation With Gypsiferous Mine Water On Soil Properties And Drainage. WRC Report No. 858/1/02 Water Research Commission, Pretoria, South Africa.

ANNANDALE JG, VAN DER WESTHUIZEN AM, DE JAGER PC, RETHMAN NFG, JOVANOVIC NZ, MODISANE PC, BELETSE Y, TESFAMARIAM E, SMITH HJC, BENADÉ N, HODGSON F, USHER B, VERMEULEN D and LORENTZ S (2004) Predicting the Environmental Impact and Sustainability of Irrigation with Gypsiferous Mine Water. Report to the Water Research Commission by Department of Plant Production and Soil Science, Faculty of Biological and Agricultural Sciences, University of Pretoria, Pretoria, 0001, South Africa. WRC Report No. 1149. Water Research Commission, Pretoria, South Africa.

DOMENICO PA (1987) An analytical model for multidimensional transport of a decaying contaminant species. J. Hydrol. 91 49-58.
DWAF (2005) Minimum Requirements for Water Monitoring at Waste Management Facilities. Department of Water Affairs and Forestry, Pretoria, South Africa.

GROBBELAAR R and HODGSON FDI (1997-2001) Groundwater monitoring at Irrigation Pivots. Confidential report for University of Pretoria, South Africa.

GROBBELAAR R, USHER BH, CRUYWAGEN L-M, DE NECKER E and HODGSON FDI (2002) The Long-term Impact of Intermine Flow from Collieries in the Mpumalanga Coalfields. WRC Report No. 1056/1/04 Water Research Commission, Pretoria, South Africa.

HENSLEY M (2006) Personal communication. Dept of Soil Sciences, University of the Free State, Bloemfontein, South Africa.

HUTSON JL (1983) Estimation of Hydrological Properties of South African Soils. Unpublished Ph.D. Thesis, University of Natal, Pietermaritzburg, South Africa.

PARKHURST DL and APPELO CAJ (1999) User's Guide to PHREEQC (Version 2) A Computer Program for Speciation, Batch-Reaction, One-Dimensional Transport, and Inverse Geochemical Calculations. US Geological Survey Water-Resources Investigations, Report No. 99-4259.

STUMM W and MORGAN JJ (1970) Aquatic Chemistry ( $2^{\text {nd }}$ edn.) John Wiley \& Sons, Inc., New York, NY. US Geological Survey, US Department of the Interior.

USHER BH (2003) Development and Evaluation of Hydrogeochemical Prediction Techniques for South African Coalmines. Unpublished Ph.D. thesis, University of the Free State.

USHER BH and ELLINGTON R (2002) Groundwater monitoring at Irrigation Pivots. Confidential report for University of Pretoria, South Africa.

USHER BH and VERMEULEN PD (2003-2006) Monitoring reports for Irrigation Project: Syferfontein Colliery, Kleinkopje Colliery and New Vaal Colliery. Confidential report for University of Pretoria, South Africa.

VERMEULEN PD, USHER BH and VAN TONDER GJ (2008) Determination of the Impact of Coal Mine Water Irrigation on Groundwater Resources. Water Research Commission Report 1507/1/08, ISBN 978-1-77005-690-9. 230-236. 